\title{
CROSS-SECTORAL COOPERATION TOWARD A WORK-LIFE BALANCE
}

\begin{abstract}
The article focuses on the introduction of two Work-Life Balance (WLB) models developed and implemented in the United States of America (the USA) and in the European Union (the UE). Main characteristics and assumptions connected with both models are presented.

In recent years policies favoring the reconciliation of work and private life have gained great attention of many EU Member States, but still number of obstacles can be identified, including: a lack of knowledge about possible solutions and their results (both employers and employees), a lack of information and advisory support for both groups of stakeholders, or lack of some effective methods of cooperation between the representatives of different sectors for the implementation of WLB practices in general.

Some tools used to overcome the pointed-out limitations for implementing WLB solutions in EU countries are programs co-financed by the budgets of their national governments and the European Social Fund (ESF). An example of such tools used toward supporting WLB practices in Poland is a project co-financed by the EU under the POWER 4.3 ESF campaign called "Cross-sectoral cooperation toward WLB based on cooperation models and tools from Great Britain".

The article presents the project as an example of good practice from Poland and describes innovative products developed in the project, including three models of cross-sectoral cooperation between employment agencies and training institutions, CSOs, and employers toward WLB.
\end{abstract}

Keywords: social innovation, Work-Life Balance, labor market, cross-sectoral cooperation, family.

\section{INTRODUCTION}

The Work-life balance (WLB) concept was developed in the United States of America (USA) during the 1970's and 1980's in response to an increase in the number of employees who were showing a decrease in commitment, a lack of enthusiasm and a decline in labor productivity. The researchers concluded that these negative behaviors of employees had been the result of an imbalance between their private and professional lives. The extent of the issue was so serious that the problem began to attract the interest of state authorities and transnational institutions, which resulted in the application of specific legal regulations. On

${ }^{1}$ Damian Liszka, PhD, Institute of Philosophy and Sociology, The Pedagogical University of Cracow, e-mail: damian.liszka@up.krakow.pl. ORCID: 0000-0002-2192-1672.

2 Paweł Walawender, PhD, Institute of Philosophy and Sociology, The Pedagogical University of Cracow, corresponding author, e-mail: pwalawender@poczta.onet.pl. ORCID: 0000-0003-4573-5759 . 
the other hand, at an organizational level, projects were implemented that were aimed at improving the situation and assisting workers in maintaining the proper harmony (balance) between work and family life. The coexistence of both areas allows for better results rather than limiting one of them. Over time, relaxing professional and private life began to be treated as one aspect of the areas of corporate social responsibility (CSR).

Apart from the state and businesses - local governments, employer associations, unions, civil society organizations (CSOs), churches, training and employment agencies, or media also have an impact on the balance between work and private life (Borkowska [red.] 2004). Due to the multiplicity of actors involved in the creation of favorable conditions for the implementation of the ideas of WLB, it becomes crucial to develop some solutions and instruments that enable different actors to cooperate effectively toward a common goal. The answer to this need is a project carried out by BD Center Ltd. and called "Cross-sectoral cooperation for work-life balance based on cooperation models and tools from Great Britain". The purpose of this article is to outline the WLB ideas and tools developed within the framework of the aforementioned project.

\section{WORK AND FAMILY LIFE IN THE POST-INDUSTRIAL ERA}

We live in an era in which the so-called practical use of knowledge rearranges social order; at least to the extent in which the steam engine in did for eighteenth-century English society. Productivity and economic competitiveness are less and less dependent on material factors of production, i.e., on resources of capital and labor; and more and more on the state of technical, economic and organizational knowledge (Kabaj, 1998). The source of economic wealth is focused intelligence and the ability to acquire and practically apply knowledge (Handy, 1996). The so-called knowledge based economy has emerged from the era of the new economy. Behind the transformations in the economy follows an evolution of society, that in the wealthiest countries deserves to be called post-industrial, that is, in which the main source of livelihood for most people is more the production of information and services than material goods. In this new, reorganized world, both spheres of life family and work - are changing.

In the sphere of work, these changes include both the area of work content, organization and working conditions, as well as changes in the working staff themselves (including changes in the structure of education, qualifications and competence traits, adaptation to work requirements, and an increase in expectations as regards working conditions) as well as changes in business organizations (Borkowska [red.] 2004). Looking through the prism of WLB, two issues are emphasized: the process of moving away from the classical pattern of employment for employees (the evolution of the legal employment relationship) and the intensive development of non-employment forms of work (flexible, atypical forms of employment, teleworking, et cetera) (Szylko-Skoczny, 2004).

Enterprises of the globalization era are primarily enormous corporations, functioning in accordance with the strategy - from high volume to high value and which have a relatively low demand for permanent employment. On the peripherals of these enterprises, or rather global networks there are employees and workers engaged in performing specific activities, providing specific services or even some elements of fixed assets (offices buildings, factory halls and others) (Reich, 1996). The time of engagement for the employee or worker is strictly defined and adapted to the strategic concepts of the creative team. Since the workforce is seen through the prism of costs in the world of global competition, limiting 
permanent or stationary work appears to be the one and only way to achieve and maintain competitiveness in the conditions of market fluctuations (Kryńska, Czerniewska [red.] 1998). Back in the 1990's, Charles Handy correctly predicted that this way of organizing the work of corporations and the dissemination of the organization model, coined by him as "[...]clover-shaped work organization" (Handy, 1998) would result in less than half of the active people finding "proper" full-time jobs in organizations operating in modern economies (Handy, 1998). Permanent and full-time (and those which do not specify end time for the contract) employment is seen as a kind of privilege in these conditions. It should be added that the increasingly common phenomenon of part-time jobs results not only from the varied needs of working staff, but also from the diversified needs of the employees themselves, who sometimes seek work for a few hours a day or attend non-employee training in order to maintain a household. Limiting the scale of full-time employment is just one of the aspects related to the globalization of the process of making the labor market more flexible. This term is usually understood as a more and more frequent application of nonstandard forms of working - it is work in a form other than traditional (Kryńska, 2001). By their nature, these new forms can be called more liberal than the thus far commonly used "social" employment rules (Drozdowski, 2002).

Such "flexible" forms of employment include: part-time work based on a permanent employment contract (indefinite or definite duration); occasional work, based on the employer's needs; shared work, when the duties of one job are undertaken by two or more people; homeworking - a job performed at home (also called teleworking); sub-contracting - when a company signs a contract with a self-employed worker; working on the basis of a mandate contract. The term "on-call work" or "commissioned work" is often used (Kozek, 2013).

The emergence of these new forms of employment and the new patterns of work organization was possible inter alia due to the development of information and communication technologies (ICT). These new technologies contribute to a faster flow of information, facilitate the processing of data and, above all, enable working remotely from a traditionally understood workplace (Skórska, 2016).

The consequence of further technological progress, especially in the IT field will be the virtualization of work (and the work environment), which in turn will result in an even higher increase of productivity outside the work office. Virtualization is considered to be a step forward in relation to teleworking (Prokurat, 2016). It is also worth mentioning that in organizations that have not yet used teleworking, a shift from traditional forms of employment in favor of some "flexible" ones has been noted. According to the "US compensation Polices and Practices Survey" released by Mercer in 2012, it was found that 65\% of US companies offer flexible start and finish times for work and allow shorter working days for increased productivity (Prokurat, 2016).

The changes taking place in the labor market have a strong relationship with demographic processes, especially those strongly connected with the development of matrimonial and procreational attitudes ${ }^{3}$. In the era of economy, which rewards working staff for their knowledge, the effort to attain the highest possible level by them lengthens the duration of their studies or training. After obtaining a satisfactory level of education, there is the socalled education-to work transition stage that in the case of young people who have no or little work experience, is sometimes prolonged due to the lack of their obtaining a desired

\footnotetext{
3 The phenomena are referred to in the so called the second demographic passage theory.
} 
job or their finding employment that corresponds to the specific expectations of youth. From the moment a young person begins working, the period in which the employee strives to strengthen their professional position due to, for example, the relatively frequently occurring worry about losing one's job on the one hand, and the prospect of higher earnings on the other hand. This period is sometimes called the postponement syndrome of the decision to start a family. In turn, starting a family later usually results in a small family. It often happens that this postponement may lead to the complete abandonment of family life by choice or through necessity (Balcerzak-Paradowska, Sadowska [red.] 2008).

\section{MODELS AND WLB TOOLS}

In the article there is reference to two major WLB models: American (referring to the USA) and European (referring to the EU in general). The former is characterized by the dominance of voluntary activities of the employers themselves toward the shaping of the WLB model, known as "work-life programs" (Borkowska, 2010). The model is characterized by a motivational approach, which means that the selection of WLB tools is varied in different sectional groups of employees with regard to their type and prosperity. The basis for this differentiation is the type of determinants of the lack of WLB and the assessment of the usefulness of the working staff (a group of them) for the organization. The American WLB model is focused on acquiring valuable working staff for the company, maintaining them in the company, creating conditions for achieving the best work output (releasing a person from everyday worries, stress, et cetera) and their personal development. In addition, the model is oriented toward the low taxation of labor costs, which favors the creation of job positions. The American model is less focused on dividing the job positions already existing between a larger number of people (for instance by applying part-time jobs, or through the development of flexible, or atypical forms of working) (Borkowska, 2010).

On the other hand, the EU WLB model, which appeared in Europe after the Second World War, has strongly developed social aspects and is obligatory for employers. Its foundations are legislative framework and social dialogue. The WLB model is focused on profamily policy and the development of atypical employment and work organization (Borkowska, 2010).

As the already extensive literature on the subject states, efforts to balance work and family in the EU are carried out in four main areas (Głogosz, Sadowska [red.], 2008):

1. Elastic work organization and flexible work.

2. Holidays and employee leave with financial benefits.

3. Caring for dependents.

4. Some additional rights or benefits granted to employees by employers.

Within each of these areas there are various tools and practices applied that vary depending on the specific EU country - its traditions, economic development and labor market legislation. Attention should be paid to the multiplicity of these tools and the differences in their naming. For instance, in Poland, up to fifty-nine of these WLB tools have been listed and described on the national portal of the Ministry of Family and Labor ${ }^{4}$. Making certain generalizations, it seems that WLB tools can be assigned to the above-noted areas in the following way (European Commission. 2005):

\footnotetext{
${ }^{4}$ Available at: https://rodzinaipraca.gov.pl/narzedzia-godzenia-rol/ (Access: 18.07.2018).
} 
1. Elastic work organization and flexible work:

a) Shortening of work time,

b) Limiting of jobs performed at night, on Sundays and holidays, in shifts (especially when they include night shifts),

c) Part-time work,

d) Telework (working from home),

e) Fixed-term work, including replacement work.

2. Holidays and employee leave with financial benefits:

a) Maternity leave with benefits,

b) Paternity leave with benefits,

c) Parental leave,

d) Leave and care allowances (for instance in the case of illness of a family member),

e) Adoptive leave (in the case of adopting a child),

f) Nursing leave (in a situation where it is necessary to provide emergency care to a dependent family member),

g) Long-term employee holidays granted for personal reasons (including family ones).

3. Caring for dependents:

a) Co-financing nurseries and kindergartens,

b) Providing rooms for childcare,

c) Providing babysitters,

d) Subsidizing or financing childcare outside of the family,

e) Emergency financial assistance for childcare,

f) Organization of summer recreational activities for children of employees.

4. Some additional rights or benefits granted to employees by their employers in the areas of:

a) Holidays and vacation (co-financing employees' holidays),

b) Care for children and other family members (co-financing to care for a child or dependent in an emergency),

c) Healthcare and insurance (providing group life insurance, employee pension schemes),

d) Sport and recreation (providing sports passes, or the organization of sport and recreation activities for working staff),

e) Education (school kits for employees' children),

f) Integration (organization or financing trips and employee integration meeting(s).

\section{AN EXAMPLE OF GOOD PRACTICE FROM POLAND}

Although in recent years policies favoring the reconciliation of work and private life have gained great attention in many EU Member States, its implementation faces a number of barriers or obstacles. Some of the major ones include (Głogosz, Sadowska-Snarska [red.], 2008):

1. A lack of knowledge about possible solutions and their results (both employers and employees); 
2. A lack of information and advisory support for both groups of stakeholders that can allow perceiving the possibilities of profits for each of them (accordingly to the win-win strategy);

3. Lapses in work organization; such as expecting working staff to accomplish more tasks than is feasibly possible during the standards of work time;

4. More focus on the feedback from the staff and managers who are not covered by the benefit program than on the positive outputs for the covered stakeholders;

5. Cases of benefit programs with unbalanced benefits or costs (often strongly focused on the economic profit of a company and subordinating the forms of a staff member to achieve the main goal).

Beside the above mentioned obstacles, one more should also be added- the lack of some effective methods of cooperation between the representatives of different sectors for the implementation of WLB practices in general (for example, due to different legal bases or an unwillingness to cooperate with different institutional sectors, or a lack of knowledge about the possibility of such cooperation), which would be included in the framework of procedures or good practices possible for implementation under the current national legislation.

Some tools used to overcome the pointed-out limitations for implementing WLB solutions in EU countries may be programs co-financed by the budgets of their national governments and the European Social Fund (ESF). For instance, in Poland such programs include the so-called "Operational Knowledge, Education, and Development Program" (acronym "POWER" in Polish) and Axis IV programs ("social innovations and transnational cooperation") managed by public Intermediate Bodies (IBs): The Ministry of Development (POWER 4.1 and POWER 4.2 Intervention campaigns) and the Center for European Projects (POWER 4.3 Intervention campaign).

An example of such tools used toward supporting WLB solutions in Poland is a project co-financed by the ESF under the POWER 4.3 campaign. It has been developed and implemented by BD Center Ltd. and is called "Cross-sectoral cooperation toward WLB based on cooperation models and tools from Great Britain"5. The project's main products and solutions implemented in Poland are based on tools that have been successfully used in the United Kingdom (UK). The target groups of the project are on one hand institutions and their employees, or even volunteers (including labor market institutions, employers, NGOs), and on the other hand inactive or unemployed people who are caring for dependents ${ }^{6}$.

The main product of the project is a web-based platform devoted to the reconciliation of work and private life ${ }^{7}$. Some main elements of the platform include ${ }^{8}$ :

5 ESF Project no POWR.04.03.00-IP.07-00-001/15

${ }^{6}$ The process of project's products development has been supported by social consultations with the possible products' users, including three experts meetings with 30 working and 10 not working adults living in Subcarpathian region and by testing of the products by 100 working and 20 not working individuals living in the region.

7 The platform is available at: http://wlb.e-wspolpraca.pl/ (Access: 18.07.2018). It was created as a tool with a basic interface and easy-to-use features, so it can be accessed by a wide group of users, including the ones with low computer skills.

${ }^{8}$ All the listed products are free to access and available to use without the need for registration on the platform. 
1. A set of fifteen animated training videos for employers that aim to inform them of the benefits of their implementing instruments that help reconcile the private and professional lives of their employees. ${ }^{9}$

2. E-learning, consisting of four interactive course modules (the psychological basis of WLB; the benefits of implementing WLB; WLB tools; and WLB strengthening policies). ${ }^{10}$ Each module has assigned a dedicated intro including two short movies of good practices from the UK showing how WLB tools are implemented by the different sectors and in the various professions in the UK.

3. Developed three models of intersectoral cooperation between employment agencies and training institutions, CSOs, and employers.

4. Public and free-to-use database with a list of current activities/initiatives, as well as institutions working to reconcile work and family life

5. A collection of new analytical materials created during the project (research reports, desk research analyses) and existing documents (articles, legal acts, reports, et cetera) about WLB.

The project's products include many references to the WLB practices in use in the UK, including intros to e-learning modules and in some training animations for employers. All instructions and other materials presented on the platform were created based on current legal provisions in force in Poland ${ }^{11}$.

In the project, particular attention is paid to the problem of WLB implementation in organizations and to the cooperation between organizations originating from various sectors. The term cross-sector cooperation requires some further comment. It can be understood in the project as a cross-sectoral partnership or strategic alliance of organizations representing various sectors of social life, which is concluded for cooperation toward common goals, to which all partners bring their competences and resources, in which they share not only risk and costs, but also share the benefits of achieving the common partnership goals and objectives of the individual organizations in the partnership (Tennyson, 2003; Jamrozik, Zmysłowski, 2010).

The aspects of this cooperation - based on certain rules and procedures - are described in the multi-part document accessible on the platform entitled "Models of cross-sectoral cooperation of the employment agencies and training institutions-CSOs-employers".

According to the guidelines of the document, the cooperation should start at the micro level (model No. 1): that is between the local enterprise, the employment agency or training institution, and the CSO. A dedicated instrument crucial at this point, before cooperation is initiated, is the usage of a multi-dimensional questionnaire developed in the project called the "WLB Questionnaire" within a single organization (by both the employer and the employees, or volunteers depending on the organization's profile). There is one questionnaire of twenty-four questions targeting working staff and the other twenty-six questions are for the managerial staff of an organization. The tool is aimed at making the staff of the organization aware of the usability of all flexible forms of employment. On the other hand, the questionnaire is to be the impulse that makes the entrepreneurial and managerial level staff aware of the need to introduce changes in the organization. Once the results of the reviews are available, the next step is to correlate the expectations of the working staff with the

\footnotetext{
9 Available at: http://wlb.e-wspolpraca.pl/bazy/szkolenie-multimedialne (Access: 18.07.2018).

${ }^{10}$ Available at: http://wlb.e-wspolpraca.pl/kursy-e-learningowe (Access: 18.07.2018).

${ }^{11}$ Legal provisions as of 1st Jan. 2017.
} 
"views" of the managerial level of the company and the available economic resources of the organization that can be used to implement some of the WLB solutions. The third step is to propose some WLB solutions and discuss them with working staff during individual meetings with managers/employers in order to fit the needs of an individual worker. The final step within an organization - particular WLB solutions should be implemented. During the implementation of the solution a local partnerships can be started within the company and CSO, or training, or employment agency (depending on the needs and the WLB tools implemented).

The next level of building effective cross-sector cooperation is at a regional level (model No. 2). This model is based on an instrument called "WLB Training". It is addressed at various target groups including, in particular, to university graduates in the so-called schoolto-work transition because these are the people who will mostly become more active in the labor market in the near future. Therefore, it is very important that these people have knowledge in the field of flexible forms of employment, their work-related rights and the tools that allow a balance of work and private time. The training is also dedicated to people working in medium and large enterprises as well as labor market institutions and CSOs at the regional level. It is advisable to organize the training with participants representing different sectors' regional organizations, so the partnership can be started even during the training. The training, besides introducing the WLB idea and existing tools to the participants, introduces them to some possible form of cooperation and to the realization of common projects ${ }^{12}$.

The third possible cooperation model can be realized at a macro level (model No. 3). The model consists of the implementation of WLB "Good Practices" in Poland in general. They can refer to the practices which are already existing and in use in the other EU countries, including Great Britain. Model No. 3 is an overall idea rather than particular recommendations, since it should take into account the ever-changing legislative statutes targeting the labour market, some overall condition of the Polish economy, demographic challenges, the economic possibilities of Polish companies and the government, and also other influencing factors. Nevertheless, some possible ways of developing WLB practices in Poland can take a turn toward: fixed employment, strengthening the infrastructure and availability of facilities for childcare and the elderly, combatting some parenting stereotypes, or the government rewarding organizations that use some good practices concerning WLB.

These three models of cooperation form one coherent whole that leads to a common goal - the inter-sectoral cooperation between private enterprises, labor market institutions and CSOs at all levels of the socio-economic structure.

\footnotetext{
12 Once the results of the reviews are available, the next step is to correlate the expectations of the working staff with the "views" of the managerial level of the company and available economic resources of the organization that can be used to implement some WLB solutions. Third step is to propose some WLB solutions and talked them over with working staff during individual meetings with managers/employers to fits the needs of an individual worker. The final step within an organization - WLB solutions should be implemented. During the implementation of the solution a local partnership can be started within company and CSO, or training, or employment agency (depending on the needs and WLB tools implemented).
} 


\section{CONCLUSION}

In the face of the growing demographic burden of developing favorable conditions in the professional life of parents, as well as overcoming barriers in the reconciliation of work and family life, it has become an important area for EU, national and regional social policy. Applying solutions that would facilitate the harmonization of activities in these two closely related areas of life - professional work and family duties - may affect, on the one hand, an increase in labor productivity and the competitiveness of enterprises in the labor market; and on the other - an in increase in motivation and employees, and their job satisfaction. Unfortunately in Polish companies, in contrast to companies from the so-called old EU, despite the existing legal solutions, WLB tools are still seldom used, particularly in atypical forms of employment. The barrier is often ignorance of these solutions or the complexity of their application or accountability (BD Center sp. z o.o., 2016) ${ }^{13}$. Therefore, it is important to properly prepare management staff and raise their level of knowledge concerning WLB. These activities can be effectively carried out within the framework of projects financed from EU funds, an example of which was the implemented project, "Cross-sectoral cooperation for WLB based on cooperation models and tools from Great Britain".

\section{REFERENCES}

Balcerzak-Paradowska, B. (2008). Polityka rodzinna w Polsce w aspekcie godzenia życia zawodowego i rodzinnego [w:] Sadowska, C., Li, T., red., Godzenie pracy z rodzina w kontekście aktywizacji zawodowej kobiet. Białystok: Wyższa Szkoła Ekonomiczna w Białymstoku.

Borkowska, S. (2004). Praca a życie pozazawodowe [w:] Borkowska, S., red., Przyszłość pracy w XXI wieku. Warszawa: Instytut Pracy i Spraw Socjalnych.

(2010). Równowaga między praca a życiem pozazawodowym. Acta Universitatis Lodziensis, Folia Oeconomica nr 240.

Drozdowski, R. (2002). Rynek pracy w Polsce. Recepcja. Oczekiwania. Strategie dostosowawcze. Poznań: UAM

European Commission (2005). Reconciliation of Work and Private Life: A Comparative Review of Thirty European Countries. Luxembourg: Directorate-General for Employment, Social Affairs and Equal Opportunities Unit G.1, Office for Official Publications of the European Communities.

Głogosz, D. (2008). Kierunki działań na rzecz godzenia obowiązów rodzinnych z obowiązkami zawodowymi - doświadczenia krajów zachodnich [w:] Sadowska, C., Li, T., red., Godzenie pracy $z$ rodzina $w$ kontekście aktywizacji zawodowej kobiet. Białystok: Wyższa Szkoła Ekonomiczna w Białymstoku.

- (2008). Rezultaty programów Praca - Życie w krajach UE - korzyści dla pracowników i ich rodzin [w:] Sadowska-Snarska, C., red., Równowaga. Praca-Życie - Rodzina. Białystok: WSE.

Handy, Ch.B. (1996). Wiek paradoksu. W poszukiwaniu sensu przyszłości. Warszawa: ABC. — (1998). Wiek przezwyciężonego rozumu. Warszawa: Business Press.

Jamrozik, M., Zmysłowski, M. (2010). Partnerstwo bez granic. Warszawa: Centrum Projektów Europejskich.

${ }^{13}$ Rozwiazania na rzecz godzenia życia zawodowego i rodzinnego w Polsce. Raport z pogtębionej analizy danych zastanych, październik 2016, BD Center Sp. z o.o. 
Kabaj, M. (2008). Strategie i programy przeciwdziałaniu bezrobociu. Studium porównawcze. Warszawa: Scholar.

Kozek, W. (2013). Rynek pracy: perspektywa instytucjonalna. Warszawa: Wydawnictwa Uniwersytetu Warszawskiego.

Kryńska, E. (2001). Dylematy polskiego rynku pracy. Warszawa: Instytut Pracy i Spraw Socjalnych.

- (1998). Popyt na prace w Polsce - tendencje i perspektywy [w:] Czerniewska, H., red., Praca i polityka społeczna w perspektywie XXI wieku. Warszawa: Instytut Pracy i Spraw Socjalnych.

Prokurat, S. (2016). Praca 2.0. Nie ukryjesz się przed rewolucja rynku pracy. Gliwice: Wydawnictwo Helion.

Reich, R.B. (1996). Praca narodów. Przegotowanie się do kapitalizmu XXI wieku. Toruń: Adam Marszałek.

Rozwiazania na rzecz godzenia życia zawodowego i rodzinnego w Polsce. Raport z pogtębionej analizy danych zastanych, październik 2016, BD Center Sp. z o.o.

Skórska, A. (2016). Rynek pracy. Wybrane zagadnienia. Katowice: Wydawnictwo Uniwersytetu Ekonomicznego w Katowicach.

Szylko-Skoczny, M. (2014). Zmiany w modelu pracy. „Studia Ekonomiczne” 167.

Tennyson, R. (2003). Poradnik partnerstwa. The International Business Leaders Forum (IBLF) and the Global Alliance for Improved Nutrition (GAIN).

DOI: $10.7862 /$ rz.2019.hss.6

The text was submitted to the editorial office: June 2018.

The text was accepted for publication: March 2019. 